\title{
The influence of structured guidance on pre-service teachers' blog writing
}

\author{
Youngju Lee \\ Korea National University of Education
}

\begin{abstract}
The purpose of the study was to investigate how structured blogging influences pre-service teachers' writings. In this study, pre-service teachers were provided with structured guidance for blog writing to support their instructional media development, undertaken as part of their teacher education course. Content analysis was conducted to examine the distribution of the types of statements and feedback in the blog posts. The proportion of statements varied depending on the sub-topics of the posts. A large number of descriptive statements were identified in the sub-topics which asked for lesson objectives and methods of instructional media use. However, in cases where the rationale for media use was requested, a great number of evaluative statements were found. Reflective statements dominated under the sub-topic of descriptions of the pre-service teachers' impressions of instructional media development. The most prominent feedback types in the blog comments and replies were social and affirmative. The pre-service teachers rarely used critical or suggestive feedback. However, reflective types of feedback occurred more in their replies than in their comments.
\end{abstract}

\section{Introduction}

Blogs, short for web logs, enable us to write about thoughts and experiences, gather together posts and easily share them with others. In particular, blogs allow us to upload not only texts but also multimedia materials such as images, videos and audio files. With the availability and easy accessibility of free blogging accounts, the number of blog users has increased steadily (Top, 2012).

Most blogs are used for personal writing, but blog use for educational activities has also enjoyed some popularity. Students collect information, critically analyse collected data and compare relevant opinions while writing up their blogs. In this way, blogging promotes students' analytical thinking (Richardson, 2010). Moreover, blogs make it easy for users to organise collected data, which means that blogs can function as online portfolios. Using blogs as an online collection makes it possible to share ideas with others, which facilitates collaborative learning communities (Halic, Lee, Paulus, \& Spence, 2010; Williams \& Jacobs, 2004). Lastly, students can look back on their learning outcomes and read peers’ posts and comments, which can encourage their reflective thinking (Hall \& Davison, 2007).

Some researchers suggest that blogging can benefit teachers' reflections on and critical analysis of teaching behaviours, eventually leading to the improvement of teaching skills and successful professional development (Ladyshewhky \& Gardner, 2008; Tang, 2009). For instance, Stiler and Philleo (2003) engaged pre-service teachers in keeping a journal on a blog about reading materials and class activities for an educational technology course during two semesters. They found that the journal entries became increasingly longer, more analytical and evaluative from one semester to the next. On the other hand, Killeavy and Moloney (2010) reported that the blog posts of beginning teachers illustrated teaching practices rather than analysis or a reflection on practice. They concluded that the use of blogs as a support for reflection requires more direction and guidance.

The contradictory results of teachers' blog content may be due to the use of non-structured guidance for blog writing. In teacher education contexts, teachers write freely on the blog without specific guidelines of how to write and what to write about. When instructors are not clear about their intention for using blogs and do not provide specific writing guidance, learners can be confused, which may interfere with their reflective writing (MacBride \& Luehmann, 2008; Top, Yukselturk, \& Inan, 2010). Therefore, in order to maximise the benefits of educational blogs, instructors need to have more concrete and structured plans for blog writing.

Another limitation of previous studies on teachers' blogging is that the methods chosen for analysing the blog texts were vague. Many of the studies did not explain in detail the units of analysis, the generation process of the coding categories or the definitions of the categories. The majority of them relied on participants' self-reports, including surveys and interviews to examine teachers' perceptions of and 
feelings about educational blogs (e.g., Dickey, 2004; Stiler \& Philleo, 2003; Tang, 2009). Few studies have employed content analysis to evaluate the quality of blog posts (e.g., Loving, Schroeder, Kang, Shimek, \& Herbert, 2007; Wopereis, Sloep, \& Poortman, 2010). As teachers tend to passively read posts and rarely participate in interactive activities such as commenting on others' posts (Top et al., 2010), prior research has focused mainly on blog posts. A more accurate picture in the assessment of teachers' blog use needs to include the analysis of comments as well as the blog entries.

In this study, pre-service teachers were asked to use blogs (with structured guidance) as they produced instructional media in a teacher certificate course. The study investigated how the nature of structured guidance impacted their writing. The study applied content analysis to blog posts, comments to posts and replies to comments. Specific research questions were as follows:

(1) How does structured guidance influence the types of statements made in blog posts?

(2) What are common or distinctive characteristics of comments to posts and replies to comments?

\section{Literature review}

Blogs initially appeared in the late 1990s and their use and popularity expanded rapidly. With their convenient usability and functional benefits, blogs came to be used for teacher education. Many teachers recognised the educational value and potential of blogs (Kuzu, 2007; Wang \& Hsua, 2008). They also reacted positively to the fact that blogs are easy to use, convenient for exploring and sharing resources (Loving et al., 2007) and beneficial for communicating and interacting with people (Kuzu, 2007; Makri \& Kynigos, 2007). Dickey (2004) suggested that blogs could be effective in reducing feelings of isolation in a Web-based learning environment and contributing to establishing a sense of community; through reading peers' blog posts, pre-service teachers realised that they were not alone and that other people had similar concerns or problems. Similarly, in Top's (2012) study, pre-service teachers reported that blogs were helpful for building an effective learning community by sharing knowledge and experiences with others and establishing a sense of belonging.

Applications of blogs in teacher education are varied: In one study, pre-service teachers were asked to keep a journal by posting their thoughts on reading materials in a teacher certificate course (Stiler \& Philleo, 2003). In other studies, in-service teachers and pre-service teachers were encouraged to keep a journal on the lessons they taught (Killeavy \& Moloney, 2010; Wopereis et al., 2010). In many cases, teachers were allowed to post freely, with no concrete guidance on how and what to write from the instructors. Accordingly, findings show mixed results on the analysis of the content of the blog posts. For example, a discourse analysis of weekly course content reflections (Dickey, 2004) revealed various categories in the blog posts:

- reflections on their Web-based learning

- friendship

- recollection of their own experience

- expression of feelings

- $\quad$ getting help and seeking advice from co-workers.

Wopereis et al. (2010) asked student teachers to write structured posts on the following topics:

- what actually happened

- what was important to them

- $\quad$ their resolutions or learning wishes.

The content of the blogs was analysed and categorised into two levels of reflection depth: plain descriptive - simple descriptions about what happened in the classroom and how to handle classroom problems and deeply reflective - pre-service teachers imagining themselves in the role of students. The results of the analysis indicate that there were many descriptions of classroom incidents and how they were handled but there were rarely any in-depth reflections. However, the analysis was limited in that it did not consider the influence of the sub-topics on the posts' content. The quality of the posts would 
depend on what students were asked to write about. Thus, it is necessary to analyse the quality of posts by sub-topic.

Despite teachers' positive perceptions of and high levels of satisfaction with blog use, many teachers don't actively interact with peers through blogs (Top et al., 2010). In fact, teachers use blogs mainly for data collection and the content of their blog posts merely describes facts. In short, there are few meaningful interactions occurring on blogs; consequently, blogging has not been used as a productive tool for facilitating reflective thinking. The results of Top's study (2012) indicate the need to provide more concrete and structured guidance to teachers for their blogging, as was undertaken as part of the current study.

Previous research on blogging for teacher education lacks analysis of the interactive characteristics of feedback on blog posts. Hall and Davison's (2007) study is notable in that they focused on the interactive features of blogs and explored the role of blog comments rather than the main entries. Moreover, previous studies on educational blogging that used content analysis did not describe the units of the analysis, the process of generating codes or defining the codes, which could undermine the validity and reliability of the data analysis (Killeavy \& Moloney, 2010; Stiler \& Philleo, 2003). The study by Loving et al. (2007), however, is a notable exception in that it presents a concrete process of analysis. Using Khine, Yeap, and Chin Lok's (2003) framework, Loving et al. (2007) classified the quality of thinking and information processing expressed in teachers' blogs in three major cognitive processes:

- clarification and understanding - using collected information to verify, explain, elaborate and gain insight into problems

- creative thinking - generating new ideas or solutions to problems

- critical thinking - determining the feasibility and validity of alternative solutions using collected evidence and making decisions on accepting or rejecting solutions.

The results of Loving et al.'s (2007) analysis indicate that the majority of the teachers' blogs were related to sharing lessons and resources and reflecting on their practice. Moreover, more than $75 \%$ of the blog content shows elaborated, justified or critically evaluated ideas, which evidences deep-level information processing. After considering the relevant literature, the current study employed content analysis to explore what types of statements (e.g., reflective or evaluative) and comments dominated in teachers' blog writings.

\section{Method}

\section{Participants}

The participants in this study were 24 pre-service teachers enrolled in an instructional media development course at a teacher education university in South Korea. The course aims to help pre-service teachers understand theories of media use in education and provide opportunities for them to develop instructional media that can be applied to their own classes. The participants comprised 10 male students (42\%) and 14 female students (58\%). The majority of participants were freshmen (first-year students, $79 \%, n=19$ ); the rest were sophomores (second-year students, $17 \%, n=4$ ) and a junior (third-year student, $4 \%, n=1$ ). The participants' majors included elementary education (38\%, $n=9)$, social studies education $(29 \%, n=7)$, history education $(13 \%, n=3)$, music education $(4 \%, n=1)$, and early childhood education $(4 \%, n=1)$. Most of the students $(87 \%, n=21)$ had experience using blogs prior to taking the class - mostly for searching and collecting information about their hobbies and interests, for example, popular restaurants, tourist attractions and recipes. Two students (8\%) used blogs mainly for listening to music and the other two students (8\%) used blogs for posting about their travel experiences or daily life. The participants' experiences with multimedia authoring software were as follows: $54 \%(n=13)$ had used photo-editing software such as Adobe Photoshop or Paint; 25\% $(n=6)$ had used video-editing software such as Movie Maker; $21 \%(n=5)$ had used sound-editing software such as Gold Wave; and 42\% $(n=10)$ had no experience with any of those applications. 


\section{Study setting}

At the beginning of the course, the pre-service teachers registered for N-blog, a blogging platform by Naver Corporation, and opened individual accounts. During the course lectures, the teachers learned how to use Adobe Photoshop, Movie Maker and Gold Wave. They were asked to develop three instructional media (one image, one audio and one video) for using in three lessons with their $\mathrm{K}-12$ students. They were also asked to write three blog posts with their instructional media products attached.

As structured guidance on blog writing, they were asked to write using the following sub-topics:

- $\quad$ target students, subjects, title of units, lesson objectives

- methods of instructional media use

- $\quad$ rationale for using instructional media

- $\quad$ preparation and considerations for using instructional media

- $\quad$ overall impressions of the instructional media production.

Moreover, they were encouraged to be critical and reflective in explaining their intentions in media development and their plans for how they would use the media in the classroom. Examples of high quality posts and feedback were provided as a part of the guidance.

After posting their opinions, the pre-service teachers were asked to visit the blogs of at least four peers, read the posts and view the instructional media. Then, they were asked to leave comments on the posts. All those who received peer feedback were asked to reply to each comment. To promote active participation and for increased convenience, the participants downloaded the N-blog mobile application to their smartphones. In addition, to promote interaction and participation, they were encouraged to use the N-blog alert function, which advises users when someone leaves a comment on a post.

\section{Data collection}

Data collection included text data from 72 blog posts, 895 comments and 714 replies. At the end of the semester, 10 pre-service teachers volunteered to participate in individual interviews. The interview questions concerned their general feelings and thoughts on their experience with blog post reading, writing, commenting and replying. Each interview took approximately 30-40 minutes and it was recorded and transcribed for analysis.

\section{Data analysis}

Data analysis was conducted on the participants’ blog posts, comments on posts and replies to comments. The content analysis followed procedures suggested by Poldner, Simons, Wijngaards, and van der Schaaf (2012). First, the initial category codes were extracted from the review of prior studies. Second, a research assistant and I developed the coding protocols. Third, we conducted preliminary evaluation of the codes to identify any unclear categories and indicators. Finally, we discussed any unclear codes and finalised our coding scheme, presented in Tables 1 and 2. We also asked an external expert to review and confirm the content validity of our coding scheme. To calculate inter-rater reliability, $10 \%$ of the blog textual data was used. The reliability score for the analysis of posts was $K=0.94$ (95\% CI [0.90, 0.98]) and $K=0.80(95 \%$, CI $[0.76,0.85])$ for the analysis of comments and replies. The units of analysis were a paragraph for posts and a sentence for comments and replies. The interview data were used to support the researcher's interpretations of the textual analysis for blogs. 
Table 1

Definitions and examples of statement type in posts

\begin{tabular}{|c|c|c|}
\hline Statement type & Definitions & Examples \\
\hline $\begin{array}{l}\text { Descriptive } \\
\text { statement }\end{array}$ & $\begin{array}{l}\text { Describe objective facts and phenomena } \\
\text { in the class }\end{array}$ & $\begin{array}{l}\text { This lesson plan is designed to teach } \\
\text { third grade elementary students. }\end{array}$ \\
\hline $\begin{array}{l}\text { Evaluative } \\
\text { statement }\end{array}$ & Determine the value of the decision & $\begin{array}{l}\text { In this class, listening to music is } \\
\text { required, so I think your selection of } \\
\text { audio media is the best decision. }\end{array}$ \\
\hline $\begin{array}{l}\text { Reflective } \\
\text { statement }\end{array}$ & $\begin{array}{l}\text { Look back on their instructional } \\
\text { behaviours or own experience }\end{array}$ & $\begin{array}{l}\text { When I was a student, I enjoyed the } \\
\text { visuals teachers showed us in class. Now, } \\
\text { however, I realise how much effort } \\
\text { teachers spent in developing the best } \\
\text { visuals for class. }\end{array}$ \\
\hline $\begin{array}{l}\text { Creative } \\
\text { statement }\end{array}$ & Generate new ideas or opinions & $\begin{array}{l}\text { Introducing conversation etiquette may } \\
\text { be a good way for promoting teacher- } \\
\text { student interactions. }\end{array}$ \\
\hline
\end{tabular}

Table 2

Definitions and examples of feedback type

\begin{tabular}{|c|c|c|c|}
\hline Feedback type & & Definitions & Examples \\
\hline \multirow[t]{4}{*}{ Post-related } & $\begin{array}{l}\text { Affirmative } \\
\text { feedback }\end{array}$ & $\begin{array}{l}\text { Offer specific } \\
\text { compliments and } \\
\text { encouragement }\end{array}$ & $\begin{array}{l}\text { You explained the rationale for the } \\
\text { use of instructional media well. And } \\
\text { the photos fit well with the lesson } \\
\text { objectives. }\end{array}$ \\
\hline & $\begin{array}{l}\text { Critical } \\
\text { feedback }\end{array}$ & $\begin{array}{l}\text { Indicate the weakness of } \\
\text { the media products }\end{array}$ & $\begin{array}{l}\text { The tone of voice in the video is } \\
\text { monotonous; students would be } \\
\text { bored. }\end{array}$ \\
\hline & $\begin{array}{l}\text { Suggestive } \\
\text { feedback }\end{array}$ & $\begin{array}{l}\text { Offer ideas for } \\
\text { consideration or action }\end{array}$ & $\begin{array}{l}\text { I think you need to provide more } \\
\text { information on the social issues of the } \\
\text { future. }\end{array}$ \\
\hline & $\begin{array}{l}\text { Reflective } \\
\text { feedback }\end{array}$ & $\begin{array}{l}\text { Reflect on own } \\
\text { experience and the } \\
\text { meaning of actions }\end{array}$ & $\begin{array}{l}\text { It was difficult to record the text } \\
\text { sentence by sentence to create an } \\
\text { audio media, but I thought the } \\
\text { experience would be very useful for } \\
\text { my future career. }\end{array}$ \\
\hline \multirow[t]{2}{*}{ Non-post-related } & $\begin{array}{l}\text { Social } \\
\text { feedback }\end{array}$ & $\begin{array}{l}\text { Comment on greetings, } \\
\text { friendship, social } \\
\text { conversation (including } \\
\text { using emoticons) }\end{array}$ & $\begin{array}{l}\text { It’s good to see you back. } \\
\text { Thank you for your advice. }\end{array}$ \\
\hline & $\begin{array}{l}\text { Technical } \\
\text { feedback }\end{array}$ & Identify technical errors & Your video is not working. \\
\hline
\end{tabular}

\section{Results}

\section{Content analysis of blog post statements}

An interesting pattern was found, which showed that specific types of statements dominated depending on the different sub-topics (see Table 3). With regard to the first sub-topic - Target students, subjects, title of units, lesson objectives - all 65 statements were descriptive. The other sub-topics in which a majority of the statements were descriptive were the second and fourth sub-topics - Methods of instructional media use; Preparation of and considerations for using instructional media. In these subtopics, descriptive statements comprised $85 \%$ and $65 \%$ of the coded units, respectively. Since those subtopics required students to provide factual information about whom to teach, what to teach and how to use media, it was natural that there were a large number of descriptive statements.

However, as for the third sub-topic - Rationale for using instructional media - the proportion of evaluative statements was as high as the proportion of descriptive statements (41\%). In this section, the 
pre-service teachers explained why they decided to use particular media for the instruction and they were encouraged to provide grounds for their choice in relation to the target students and lesson objectives (pseudonyms are used throughout the quotes):

When I posted, I thought about the ways I can use the media effectively for the instruction. I asked myself, "Why do I need this media? Is it the best tool?” (Interview quote from Park)

Lastly, on the sub-topic of overall impressions, the teachers wrote a great number of reflective statements in their posts (65\%). They tended to examine peers' instructional media, reflect on their own media development process and share their results with others in peer blogs. In short, according to the topics of the posts, the distribution of the types of statements varied:

I was impressed that other colleagues found something that I had not even thought about. I realized that I was not perfect. Looking at others' blogs was helpful and inspiring. I got good ideas from reading others’ posts and seeing their media products. (Interview quote from Choi)

Table 3

Distribution of statement types on post topics

\begin{tabular}{|c|c|c|c|c|c|}
\hline \multirow[t]{2}{*}{ Statement type } & \multicolumn{5}{|c|}{ Post topics } \\
\hline & $\begin{array}{l}\text { Target } \\
\text { students, } \\
\text { subjects, } \\
\text { title of } \\
\text { units, } \\
\text { lesson } \\
\text { objectives }\end{array}$ & $\begin{array}{l}\text { Methods of } \\
\text { instructional } \\
\text { medial use }\end{array}$ & $\begin{array}{l}\text { Rationale for } \\
\text { using } \\
\text { instructional } \\
\text { media }\end{array}$ & $\begin{array}{l}\text { Preparation of } \\
\text { and } \\
\text { considerations } \\
\text { for using } \\
\text { instructional } \\
\text { media }\end{array}$ & $\begin{array}{l}\text { Overall } \\
\text { impressions } \\
\text { of } \\
\text { instructional } \\
\text { media } \\
\text { production }\end{array}$ \\
\hline Descriptive & $65(100 \%)$ & $63(85 \%)$ & 34 (41\%) & $44(65 \%)$ & $9(11 \%)$ \\
\hline Evaluative & 0 & $3(4 \%)$ & 34 (41\%) & $10(15 \%)$ & $12(15 \%)$ \\
\hline Reflective & 0 & 0 & 0 & $1(1 \%)$ & $50(65 \%)$ \\
\hline Creative & 0 & $8(11 \%)$ & $15(18 \%)$ & $13(19 \%)$ & $7(9 \%)$ \\
\hline Total (\%) & $65(100 \%)$ & $74(100 \%)$ & $83(100 \%)$ & $68(100 \%)$ & $78(100 \%)$ \\
\hline
\end{tabular}

\section{Content analysis of blog comments and replies}

As shown in Table 4, the results of the analysis of blog comments indicate that the number of post-related comments (473, 53\%) slightly exceeded the number of non-post-related comments (422, 47\%). On the other hand, the number of replies that were not related to the content of the posts $(449,63 \%)$ was greater than the number of post-related replies (265, 37\%).

Table 4

Results of analysis on feedback type

\begin{tabular}{llll}
\hline \multicolumn{1}{c}{ Feedback type } & Number of comments & Number of replies \\
\hline \multirow{2}{*}{ Post-related } & Affirmative & $357(40 \%)$ & $135(19 \%)$ \\
& Critical & $20(2 \%)$ & $3(0 \%)$ \\
& Suggestive & $40(5 \%)$ & $9(1 \%)$ \\
& Reflective & $56(6 \%)$ & $118(17 \%)$ \\
\cline { 2 - 4 } Non-post-related & Subtotal & $473(53 \%)$ & $265(37 \%)$ \\
\cline { 2 - 4 } & Social & $405(45 \%)$ & $429(60 \%)$ \\
& Technical & $17(2 \%)$ & $20(3 \%)$ \\
\cline { 2 - 4 } & Subtotal & $422(47 \%)$ & $449(63 \%)$ \\
\hline Total & & $895(100 \%)$ & $714(100 \%)$ \\
\hline
\end{tabular}

A large number of comments (45\%) were social in nature and $47 \%$ were not related to posts. The teachers tended to use social greetings for friendship and the exchange of courtesies. Moreover, they habitually ended their sentences with greetings or with perfunctory praise in their feedback, which led to a high proportion of social feedback: 
The most frequent comments I received was “Nice job”. There was very little negative feedback. I think everybody feels that we all made an effort to develop the media. (Interview quote from Choi)

I always used a "Good job" comment when I suggested that others modify their products. (Interview quote from Cho)

The second most frequent comments following social comments were affirmative. They accounted for $40 \%$ of the total number of comments and $75 \%$ of the post-related comments. The teachers rarely used critical comments ( $2 \%$ of all comments generated). Furthermore, they were reluctant to criticise the work of peers in public:

I guess we were inclined to avoid critical comments because we met for the first time in this class and we did not want to hurt each other. (Interview quote from Kim)

I think critical comments could make people feel bad. I usually gave positive feedback. (Interview quote from Lee)

I felt that critical comments were something that I did not have to do because I am not an expert and the professor would provide them. (Interview quote from Oh)

The results of the analysis of replies to comments show a similar pattern to the analysis of comments. The most frequent type of reply was social (60\%), followed by affirmative (19\%). These two types comprised almost $80 \%$ of the total number. On the contrary, suggestive comments (5\%) and reflective comments (6\%) had a low rate of frequency. In the interview, students mentioned the perfunctory nature of peer feedback:

Many comments were favourable, such as “Good job”, which made me feel great but they were not actually helpful for improving my work. There were few comments that described shortcomings in my work and how to make up for them. (Interview quote from Yang)

In the beginning, everybody wrote sincerely. As time went by, people wrote just for the sake of it without thinking. (Interview quote from Kim)

Reflective feedback occurred frequently in the teachers' replies (118, 17\% of the total). The teachers tended to look back on their own experiences and the process of media development when they replied to peers' questions and suggestions:

I tried to justify my intentions for the media development and persuade people. For example, someone commented that my video looked a little tacky and unfocused. I replied to him, explaining what functions I used for the development and how I would make it better. I think blogging is a dialogue between people. People tried to interact with me by commenting on my posts. I did my best to reply to them to maintain the interaction. (Interview quote from Lee)

\section{Discussion}

In previous studies on teachers' blog use, researchers have tended to give students general guidance such as offering a broad outline or a goal for blog writing. They have not generally provided more specific and explicit guidance for what to write about and how to write, which has led to contradictory findings about the effects of blog use in teacher education: Some researchers have argued that pre-service teachers' posts are very analytic and useful for reflecting on instruction (e.g., Stiler \& Philleo, 2003). Other researchers have claimed that the content of posts is descriptive rather than introspective (e.g., Killeavy \& Moloney, 2010). To address the research gaps in previous studies, this study investigated how structured guidance influences pre-service teachers' blog writing. In particular, content analysis was conducted to examine the types of statements and feedback in pre-service teachers' comments on and replies to peers' comments.

The leading feature of the findings is that blog posts had different patterns in the types of statements depending on the sub-topics of the post. There were a great number of evaluative statements found when 
the teachers were asked to describe their rationale for their choice of instructional media. On the sub-topic of overall impressions, the teachers used a large number of reflective statements in their blog entries. This result suggests that without considering the nature of what they were asked to write about, we cannot determine whether teachers' writings in blog entries demonstrate descriptive facts or critical thinking.

The results of the analysis on types of feedback indicate that a large number of comments and replies were social and affirmative. This finding is consistent with Hall and Davison's (2007) study in which a majority of comments were encouragement and compliments. However, in the current study, the teachers' use of suggestive or critical feedback was relatively infrequent. The interview analysis reveals that they tended to abstain from giving critical feedback to peers because blog comments are neither privately delivered nor individually shared.

It is noteworthy that the teachers were likely to use more reflective feedback when they replied to others' comments. In addition, it is interesting that reflective feedback dominated participants' replies rather than their comments on posts. However, it is difficult to interpret this finding in relation to prior research due to the lack of studies conducting analyses of replies to comments in blogs. From the teacher interviews, we can infer that the teachers had an opportunity for introspection on the process of instructional media development when they wrote replies to peers' questions and suggestions.

This study contributes to the field of instructional blog use by using content analysis to explore the impact of structured guidance on pre-service teachers' blog writing. However, as this study employed a pre-post design without a control group, the generalisability of the findings might be restricted. To strengthen the external validity of the effects of structured guidance on the quality of blog writing, a group comparison study (e.g., structured guidance group vs. no guidance group) should be conducted.

\section{References}

Dickey, M. (2004). The impact of web-logs (blogs) on student perceptions of isolation and alienation in a web-based distance-learning environment. Open Learning, 19(3), 279-291. doi:10.1080/0268051042000280138

Halic, O., Lee, D., Paulus, T., \& Spence, M. (2010). To blog or not to blog: Student perceptions of blog effectiveness for learning in a college-level course. The Internet and Higher Education, 13(4), 206213. doi:10.1016/j.iheduc.2010.04.001

Hall, H., \& Davison, B. (2007). Social software as support in hybrid learning environments: The value of the blog as a tool for reflective learning and peer support. Library \& Information Science Research, 29(2), 163-187. doi:10.1016/j.lisr.2007.04.007

Khine, M. S., Yeap, L. L., \& Chin Lok, A. T. (2003). The quality of message ideas, thinking and interaction in an asynchronous CMC environment. Educational Media International, 40(1/2), 115126. doi:10.1080/0952398032000092161

Killeavy, M., \& Moloney, A. (2010). Reflection in a social space: Can blogging support reflective practice for beginning teachers? Teaching and Teacher Education, 26(4), 1070-1076. doi:10.1016/j.tate.2009.11.002

Kuzu, A. (2007). Views of preservice teachers on blog use for instruction and social interaction. Turkish Online Journal of Distance Education, 8(3), 34-51. Retrieved from http://tojde.anadolu.edu.tr/volume-8-issue-3-year-2007.html

Ladyshewsky, R. K., \& Gardner, P. (2008). Peer assisted learning and blogging: A strategy to promote reflective practice during clinical fieldwork. Australasian Journal of Educational Technology, 24(3), 241-257. doi:10.14742/ajet.1207

Loving, C. C., Schroeder, C., Kang, R., Shimek, C., \& Herbert, B. (2007). Blogs: Enhancing links in a professional learning community of science and mathematics teachers. Contemporary Issues in Technology and Teacher Education, 7(3), 178-198. Retrieved from http://www.citejournal.org/volume-7/issue-3-07/science/blogs-enhancing-links-in-a-professionallearning-community-of-science-and-mathematics-teachers/

MacBride, R., \& Luehmann, A. L. (2008). Capitalizing on emerging technologies: A case study of classroom blogging. School Science and Mathematics, 108(5), 173-183. doi:10.1111/j.19498594.2008.tb17826.x

Makri, K., \& Kynigos, C. (2007). The role of blogs in studying the discourse and social practices of mathematics teachers. Educational Technology \& Society, 10(1), 73-84. Retrieved from 
http://www.jstor.org/stable/jeductechsoci.10.1.73

Poldner, E., Simons, P., Wijngaards, G., \& van der Schaaf, M. (2012). Quantitative content analysis procedures to analyse students' reflective essays: A methodological review of psychometric and edumetric aspects. Educational Research Review, 7(1), 19-37. doi:10.1016/j.edurev.2011.11.002

Richardson, W. (2010). Blogs, wikis, podcasts, and other powerful web tools for classrooms (3rd ed.). Thousand Oaks, CA: Corwin Press.

Stiler, G. M., \& Philleo, T. (2003). Blogging and blogspots: An alternative format for encouraging reflective practice among preservice teachers. Education, 123(4), 789-798. Retrieved from https://www.questia.com/library/journal/1G1-105043958/blogging-and-blogspots-an-alternativeformat-for

Tang, E. (2009). Introduction and development of a blog-based teaching portfolio: A case study in a preservice teacher education programme. The International Journal of Learning, 16(8), 89-100. Retrieved July 18, 2017, from the EBSCO database.

Top, E. (2012). Blogging as a social medium in undergraduate courses: Sense of community best predictor of perceived learning. The Internet and Higher Education, 15(1), 24-28. doi:10.1016/j.iheduc.2011.02.001

Top, E., Yukselturk, E., \& Inan, F. A. (2010). Reconsidering usage of blogging in preservice teacher education courses. The Internet and Higher Education, 13(4), 214-217. doi:10.1016/j.iheduc.2010.05.003

Wang, S., \& Hsua, H. (2008). Reflections on using blogs to expand in-class discussion, TechTrends, 52(3), 83-85. doi:10.1007/s11528-008-0160-y

Williams, J. B., \& Jacobs, J. (2004). Exploring the use of blogs as learning spaces in the higher education sector. Australasian Journal of Educational Technology, 20(2), 232-247. Retrieved from https://ajet.org.au/index.php/AJET/article/view/1361

Wopereis, I. G., Sloep, P. B., \& Poortman, S. H. (2010). Weblogs as instruments for reflection on action in teacher education. Interactive Learning Environments, 18(3), 245-261. doi:10.1080/10494820.2010.500530

Corresponding author: Youngju Lee, agnes@knue.ac.kr

Australasian Journal of Educational Technology ( 2018.

Please cite as: Lee, Y. (2018). The influence of structured guidance on pre-service teachers' blog writing. Australasian Journal of Educational Technology, 34(3), 30-38. https://doi.org/10.14742/ajet.3094 